軽金属 第 54 巻第 10 号 (2004), 407-411

\title{
二元アルミニウム合金とマグネシウム合金の 実測密度と多元系への拡張
}

\author{
小松 伸也**池田 勝彦*・阿部 晴彦**
}

Journal of Japan Institute of Light Metals, Vol. 54, No. 10 (2004), pp. 407-411

\section{Measured density of binary aluminum alloys and magnesium alloys expanded to multicomponent systems}

\begin{abstract}
Shin-ya KOMATSU*, Masahiko IKEDA* and Haruhiko ABE**
Equation representing dependence of density on composition was deduced for dilute binary solid solutions. The constants in an expression of $D / \mathrm{kg} \mathrm{m}^{-3}=D_{0}+\Delta D\left(C / \mathrm{mass}^{\%}\right)$ were obtained from Vegard's law. For an easy calculation from contents of commercial alloys expressed commonly in mass $\%$, previously measured values of density were put in order, as functions of mass $\%$. This expression was expanded to multicomponent systems and it has been clarified that the values of $\Delta D$ determined by measurement on binary alloys are also valid for $\mathrm{Al}-\mathrm{Zn}-\mathrm{Mg}$ and $\mathrm{Al}-\mathrm{Mg}-\mathrm{Si}-\mathrm{Cu}$ systems. Using the present $\Delta D$ values, the density of rather widespread multicomponent alloys can be easily estimated, excepting $\mathrm{Al}-\mathrm{Si}$ binary system which density is increased by solute $\mathrm{Si}$ and decreased by precipitation of elemental $\mathrm{Si}$ from $\mathrm{Al}(\mathrm{Si})$ solid solution. Effect of dislocations introduced by severe cold rolling is rather small. Only about $0.2 \%$ or $5 \mathrm{~kg} \mathrm{~m}^{-3}$ decrease of density was observed in a $87 \%$ cold rolled $6 \mathrm{~N} 01$ alloy.
\end{abstract}

(Received October 23, 2003)

Keywords: density, aluminum alloys, magnesium alloys, concentration effect, dislocation effect, multicomponent systems

\section{1. 緒言}

軽金属とは『密度 $4.0 \mathrm{~g} / \mathrm{cm}^{3}$ (あるいは $5.0 \mathrm{~g} / \mathrm{cm}^{3}$ ) 以下の もの』とする定義がある ${ }^{1)}$ 。高い比強度が材料選択の重要因 子になる軽金属にとって, 密度は大切な数值である。しかし, アルミニウムで 2.7 , マグネシウムで 1.7 , チタンで $4.5 \times 10^{3} \mathrm{~kg} / \mathrm{m}^{3}$ といったように, 密度は主成分で大体決まる ため, 合金元素の種類や添加量によってどのように変化する かは従来あまり議論されなかった。

アルミニゥム合金の密度に及ぼす合金元素の影響としては, E. J. Hatch の記述が便覧 $\left.{ }^{2}\right)$ に引用されているが，変化量は \% で表されており，スカンジゥムは含まれていない。

著者らは長期間にわたって比抵抗測定を続けてきた。比抵 抗に必要なサイズファクタの決定に, 当初はマイクロメータ で試料断面積を測定したが3）, 4) 誤差が大きく， ぼることがあった。試料密度を実測しておけば，試料の全長 と質量から平均断面積が得られる。平均断面積から得られる

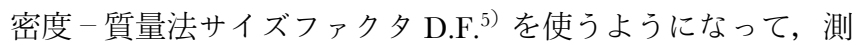
定項目は増えたが D.F.に起因する誤差は $00.1 \%$ 台に改善さ れた。

サイズファクタ誤差は比抵抗測定で重要な誤差要因の一つ である。これの有無の判定には, マティーセン則から誘導し た抵抗比 R（ $\left(=\rho_{300} / \rho_{77}\right)$ と比抵抗の関係 $\left.{ }^{6}\right)$ が有効である。 $\rho_{77}=\alpha /(\mathrm{R}-1)+\beta$ の形で表されるマティーセン則経験式の 勾配 $\alpha$ が理論値と一致しないことの原因として, 個々の溶質 が示すマティーセン則からのずれ（DMR）とノルトハイム則 の修正を考え，測定温度と溶質濃度の比抵抗への影響を検討 した7)。単純な二元系合金であっても，化学分析值と比抵抗 用試料の合金元素含有量とのわずかな相違は避けられない7)。 この変動を平均化するために意図的に組成を変えた合金の比

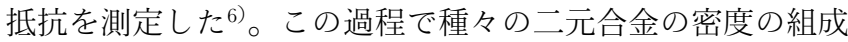
依存性が蓄積された。

実測密度は各合金系の報告ごとになるべく記載してきたが， 数值だけのものが多かった。この報告ではこれらを整理して 一般に使用しやすい形にした。ついで，これらの数值が三元 系以上の実用合金の密度推定に使用できるかどうかを実測值 と比較して検討した。結果は, 先に本会第 95 回春期大会で 発表したが，重要な数值が誤記されていたので，ここに修正 する。

\section{2. 格子定数を使った密度の計算}

面心立方晶の場合，単位構造胞中には 4 個の原子が存在す る。固溶体中の平均的な原子 1 個の質量を $m$, 固溶体の格子 定数を $a$ と書くと, 固溶体の密度 $D$ は

$$
D=4 m / a^{3}
$$

*関西大学工学部（产 564-8680 大阪府吹田市山手町 3-3-35)。 Faculty of Engineering, Kansai University（3-3-35, Yamate-cho, Suita-shi, Osaka, 564-8680).

**関西大学大学院学生 [現在：日本特殊陶業(桻（名古屋市)]。Graduate Student, Kansai University, [Present: Nippon Tokushu Togyo Co, Ltd., (Nagoya-shi, Aichi)]. 
で与えられる。 $m$ と $a$ は溶質の原子分率 $X$ とともに,

$$
\begin{aligned}
& m=m_{0}\left[1+\left(\Delta m / m_{0}\right) X\right] \\
& a=a_{0}\left[1+\left(\Delta a / a_{0}\right) X\right]
\end{aligned}
$$

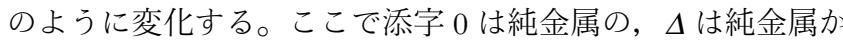
らの変化量を意味し, $\mathrm{A}-\mathrm{B}$ 二元系で溶媒 $\mathrm{A}$ の原子量を $M_{\mathrm{A}}$, 溶質の原子量を $M_{\mathrm{B}}$ と書くと, $\Delta m / m_{0}=\left(M_{\mathrm{B}}-M_{\mathrm{A}}\right) / M_{\mathrm{A}}$ とな

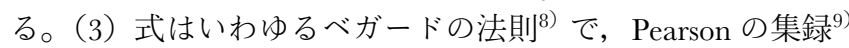
では最高 $10 \mathrm{at} \%$ 程度まで直線関係が成立する系がある。

（1）式の $m$ と $a$ に（2）式，(3) 式を代入すると近似的に

$$
\begin{aligned}
D & \fallingdotseq 4 m_{0} / a_{0}^{3}\left\{1+\left[\left(\Delta m / m_{0}\right)-3\left(\Delta a / a_{0}\right)\right] X\right\} \\
& \fallingdotseq D_{0}\left\{1+\left[\left(\Delta m / m_{0}\right)-3\left(\Delta a / a_{0}\right)\right] X\right\}
\end{aligned}
$$

が得られる5)。

最密六方晶でも同様にして,

$$
D \fallingdotseq D_{0}\left\{1+\left[\left(\Delta m / m_{0}\right)-2\left(\Delta a / a_{0}\right)-\left(\Delta c / c_{0}\right)\right] X\right\}
$$

と近似できる ${ }^{10)}$ 。

この近似は， $\mathrm{A}-\mathrm{B}$ 二元固溶体で $X$ があまり大きくない場合 には，原子 \% と密度の関係をかなりょく表している。ただし 高濃度固溶体や，原子量比が大きくて $\Delta m / m_{0}$ が大きくなる 合金系では，質量 \%で与えられた個々の合金組成から原子 $\%$ に換算し，(1)，（2）式の $m$ を厳密に計算する必要がでてく る。

溶質濃度に伴う固溶体合金の格子定数变化は，集録 ${ }^{9}$ に詳 しく集められており， $\mathrm{Al}$ との原子半径差が大きい $\mathrm{Al}-\mathrm{Mg}$ 系 ${ }^{11)}$ や $\mathrm{Al}-\mathrm{Cu}$ 系 ${ }^{12)}$ では, 格子定数が溶質濃度推定に使われ た。このように溶質濃度と格子定数の関係が求められている 二元系の希薄固溶体では（4)，（5）式から密度を計算でき る。

Table 1 に Pearson ${ }^{9 ）}$ の集録に集められたアルミニウム基固 溶体の格子定数と溶質濃度の関係から求めた $\Delta a / a_{0}$ を,

Table 2 にはマグネシウム基固溶体の $\Delta a / a_{0}$ と $\Delta c / c_{0}$ を，そ れぞれの系の $\Delta m / m_{0}$ とともに示す。同時に，(4）式，（5）式 の原子分率 $X$ にかかる項と原子 $\%$ 加質量 $\%$ の換算に必要 な原子量の比, $M_{\mathrm{A}} / M_{\mathrm{B}}$ および, 後に（6）（8）式で示す $\Delta D$ の，格子定数からの計算值屯あわせて示した。

Table 1 の $\mathrm{Al}-\mathrm{Si}$ 系では $\mathrm{Si}$ の原子量が $\mathrm{Al}$ より大きく, 固溶 した $\mathrm{Si}$ は格子定数を減少させるため, 固溶体の密度は $\mathrm{Si}$ 濃 度とともに増加する。この系では GPゾーンは出現せず，過 飽和固溶体から直接アルミニウムより密度の低い単体シリコ ンが析出するので, 固溶状態の高い密度は, 析出に伴って低 下する。 $\mathrm{Si}$ 析出状態の $\Delta D$ は, 単体シリコンの密度, $2.33 \sim 2.34 \times 10^{3} \mathrm{~kg} \mathrm{~m}^{-3}$ を使って複合則で算出した。

これらの $\Delta D$ の計算值を使えば，密度が実測されていない 合金系でも，希薄合金であれば，ある程度信頼できる密度の 推定が可能である。逆に格子定数变化が集録されていない系 では，実測が必要になる。

一般に三成分以上の系の組成は質量 $\%$ で与えられ ${ }^{13)}$ ，実 用合金は本来多元系で，それらの組成は質量％で規格され ている。二元希薄合金では原子量比の乗除で簡単に換算でき るが， $\Delta D$ が質量 \% 当たりになっていれば，密度の計算は容 易になる。
Table 1 Values of $\Delta a / a_{0}$ per atomic fraction, $\Delta m / m_{0}$ in equation (4) for aluminum base binary solid solutions and $\Delta D /\left(\mathrm{kg} \mathrm{m}^{-3} \operatorname{mass}^{0} \%^{-1}\right)$ calculated by equation (7). $\Delta a / a_{0}$ values were read from Pearson's Handbook ${ }^{9)}$, Fig. 59 on p. 346.

\begin{tabular}{c|c|c|c|c}
\hline \hline solute & $\Delta a / a_{0}$ & $\Delta m / m_{0}$ & $M_{\mathrm{A}} / M_{\mathrm{B}}$ & $\Delta D$ \\
\hline $\mathrm{Li}$ & -0.00100 & -0.743 & 3.8873 & -74.83 \\
$\mathrm{Cu}$ & -0.0927 & 1.355 & 0.4246 & 18.72 \\
$\mathrm{Ag}$ & 0.0015 & 2.998 & 0.2501 & 20.21 \\
$\mathrm{Mg}$ & 0.102 & -0.0992 & 1.1101 & -12.14 \\
$\mathrm{Zn}$ & -0.0163 & 1.42 & 0.4126 & 16.36 \\
$\mathrm{Si}$ & -0.0427 & 0.0409 & 0.9607 & $4.38(\mathrm{sol})$ \\
& & & & $-3.77(\mathrm{pcp}) *$ \\
$\mathrm{Ge}$ & 0.0467 & 1.69 & 0.3716 & 15.55 \\
$\mathrm{Cr}$ & -0.206 & 0.9271 & 0.5189 & 21.65 \\
$\mathrm{Mn}$ & -0.158 & 1.036 & 0.4911 & 20.02 \\
\hline
\end{tabular}

sol: in solution, pcp: precipitated, *: calculated by rule of mixture.

Table 2 Values of $\Delta a / a_{0}$ and $\Delta c / c_{0}$ per atomic fraction, $\Delta m / m_{0}$ and $\Delta D /\left(\mathrm{kg} \mathrm{m}^{-3}\right.$ mass $\left.^{0}{ }^{-1}\right)$ calculated by equation (8) for magnesium base binary solid solutions. $\Delta a / a_{0}$ and $\Delta c / c_{0}$ values were read by present authors from Pearson's Handbook ${ }^{9)}$, Figs. 136 and 137 on p. 728 and 729.

\begin{tabular}{c|c|c|c|l|c}
\hline \hline solute & \multicolumn{1}{|c|}{$\Delta a / a_{0}$} & \multicolumn{1}{|c}{$\Delta c / c_{0}$} & $\Delta m / m_{0}$ & $M_{\mathrm{A}} / M_{\mathrm{B}}$ & $\Delta D$ \\
\hline $\mathrm{Pb}$ & 0.0405 & 0.0989 & 7.52 & 0.1173 & 14.99 \\
$\mathrm{Li}$ & -0.0323 & -0.0726 & -0.714 & 3.502 & -35.17 \\
$\mathrm{In}$ & -0.0348 & -0.0015 & 3.724 & 0.2117 & 13.99 \\
$\mathrm{Cd}$ & -0.0663 & -0.0618 & 3.625 & 0.2162 & 14.38 \\
$\mathrm{Al}$ & -0.120 & -0.0982 & 0.110 & 0.9008 & 7.012 \\
$\mathrm{Zn}$ & -0.139 & -0.154 & 1.690 & 0.3717 & 13.73 \\
$\mathrm{Ag}$ & -0.176 & -0.2220 & 3.4380 & 0.2253 & 15.74 \\
\hline
\end{tabular}

\section{3. 実験方法}

大気中の質量と水中重量の測定には床下に水槽を上下する 装置を備えた電子天秤を使った。試料への気泡の付着を防ぐ ため, 水槽には湯煎で脱気した脱イオン水を入れた。すべて 室温でアルキメデス法で密度を測定し, 水温による水の密度 変化を補正した。試料を水中に吊るす線には, マンガン鋼極 細線をはじめとするメタル系の各種の釣糸を使った。

アルミニウム合金試料では, 試料体積ができるだけ大きい 状態，主として厚さ $3 \mathrm{~mm}$ の圧延板で測定したが一部は $0.5 \mathrm{~mm}$ または $1.0 \mathrm{~mm}$ 厚の板む用いた。最大の試料寸法は, 約 $3 \times 30 \times 200 \mathrm{~mm}$ 程度である。一部の合金では $50,87.5 \%$ 冷 間圧延状態と焼なまし状態を比較し，数值としては焼なまし 状態のものを採用した。

マグネシウム合金の鋳塊試料も, 水槽に入る寸法に切出し て測定した。試料の脱脂, 洗浄は当然であるが，マグネシウ ム合金の場合は，わずかに水と反応して発生した水素が，気 泡として試料に付着しないように注意した。

\section{4. 実験結果と測定值の吟味}

\section{1 二元系合金での測定例と組成依存性}

Fig. 1 に一例として $\mathrm{Mg}-\mathrm{Al}$ 二元固溶体での $\mathrm{Al}$ 含有量と実 


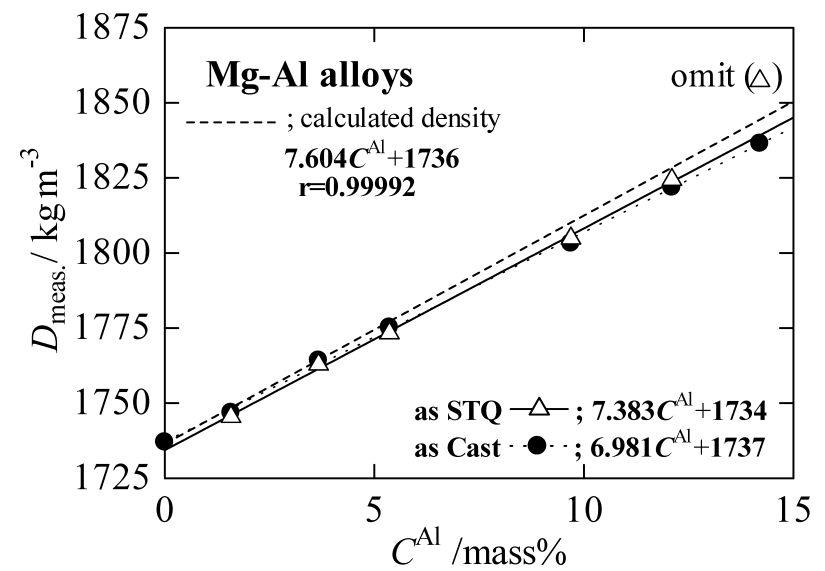

Fig. 1 Relation between $\mathrm{Al}$ content and measured density of $\mathrm{Mg}-\mathrm{Al}$ binary alloys ${ }^{13)}$.

測密度の関係を示す ${ }^{14)}$ 。 $\mathrm{Mg}-\mathrm{Al}$ 系での $\Delta a / a_{0}, \Delta c / c_{0}$ および $\Delta m / m_{0}$ を使った個々の組成からの計算值を, 回帰して破線で 記入した。Table 1 の近似計算による $\Delta D$ よりやや大きくな る。鋳造ままの状態でも, 溶体化処理材でも, 大部分の試料 の実測值は計算值にかなり近い。

実測值の回帰直線からの偏差は, 最大で $1 \mathrm{~kg} \mathrm{~m}^{-3}$ 程度で, 図中に示した回帰式の相関係数屯充分に 1 に近い。したがっ て, この方法で実験的に求めた定数を使えば， $\pm 1 \mathrm{~kg} \mathrm{~m}^{-3}$ 以 内の信頼度を持つ計算值が得られる。

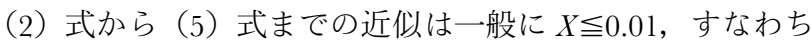
溶質濃度 $1 \mathrm{at} \%$ 以下，でよい近似として使えるとされている。 しかし, Fig. 1 では約 $9 \mathrm{at} \%$ まで，よい直線関係が得られて いる。比抵抗の場合は低濃度側のデータで引いた直線より明 らかな低下が認められ, 修正ノルトハイム則による取扱いが 必要であった。格子定数の变化に対しても溶質濃度の二次項 の寄与はほとんどなく, よい直線関係が得られている ${ }^{9)}$ 。格 子定数や密度が, 電荷のキャリアの散乱による比抵抗とは異 なった溶質濃度依存性を示すことは，当然であろう。

Table 3 に二元系固溶体で実測し，（4）および（5）式を

$$
D / \mathrm{kg} \mathrm{m}^{-3}=D_{0}+\Delta D\left(C / \operatorname{mass}_{\%} \%\right)
$$

と $\operatorname{mass} \%$ 当たりに書き直して整理した溶質単位濃度当たりの 密度変化, $\Delta D /\left(\mathrm{kg} \mathrm{m}^{-3} \mathrm{mass}^{\%} \mathrm{o}^{-1}\right)$ を, 試料の組成範囲, 回帰 式の相関係数 $r$ とともに示す。 $\Delta D$ は（4）式および（5）式 の表現から，面心立方晶のアルミニウム基固溶体では

$$
\Delta D \fallingdotseq 10^{-2}\left(M_{\mathrm{A}} / M_{\mathrm{B}}\right) D_{0}\left[\left(\Delta m / m_{0}\right)-3\left(\Delta a / a_{0}\right)\right]
$$

また最密六方晶のマグネシウム基固溶体では,

$$
\Delta D \fallingdotseq 10^{-2}\left(M_{\mathrm{A}} / M_{\mathrm{B}}\right) D_{0}\left[\left(\Delta m / m_{0}\right)-2\left(\Delta a / a_{0}\right)-\left(\Delta c / c_{0}\right)\right]
$$

に相当する。

下線をつけた数值は先の講演概要 ${ }^{15)}$ で誤記されていたもの である。Table 3 中に添えた文献番号は, 同一試料を使って 求めた比抵抗の溶質濃度依存性を中心に発表したもので, 試 料の組成や密度測定時の状態の詳細は, それぞれの文献に詳 しく書かれている。未発表の $\mathrm{Al}-\mathrm{Ge}$ 合金は， 0.9 3.6 mass\% Ge とその間の $1.8,2.6 \%$ の計 4 組成を， $50 \%$ 冷間圧延状態
Table 3 Values of $D_{0} / \mathrm{kg} \mathrm{m}^{-3}$ and $\Delta D /\left(\mathrm{kg} \mathrm{m}^{-3} \mathrm{mass}^{0}{ }^{-1}\right)$ in equation (9), composition (C) range in $\operatorname{mass} \%$ and correlation factor $r$ of regression. The $D_{0}, \Delta D$ and $r$ were

\begin{tabular}{|c|c|c|c|c|c|c|}
\hline solvent & solute & $D_{0}$ & $\Delta D$ & $C$ range & $r$ & ref. \\
\hline \multirow{13}{*}{$\mathrm{Al}$} & $\mathrm{Cu}$ & 2699 & +19.4 & $0.46-4.04$ & 0.9996 & 17) \\
\hline & $\mathrm{Mg}$ & $2699 .{ }_{8}$ & -12.5 & $0.47-8.10$ & 0.9985 & 16) \\
\hline & $\mathrm{Zn}$ & 2697 & +17.9 & $0.80-59.5$ & 0.9996 & 17) \\
\hline & $\mathrm{Sc}$ & 2699.9 & $+6.3_{2}$ & $0.060-0.360$ & 0.9917 & 21) \\
\hline & $\mathrm{Si}$ & 2698 & $+6.04_{9}$ & $0.15-1.19$ & 0.9935 & 4) \\
\hline & $\mathrm{Ge}$ & 2698.7 & $+15.7_{4}$ & $0.90-3.60$ & 0.9986 & \\
\hline & $\mathrm{Ti}$ & 2699 & $+27.1_{4}$ & $0.04-0.22$ & 0.9619 & 19) \\
\hline & $\mathrm{Zr}$ & $2699 \cdot 7$ & $\begin{array}{r}+20.4_{4} \\
\end{array}$ & $0.05-0.25$ & 0.9786 & 19) \\
\hline & V & 2698 & $+19.1_{9}$ & $0.001-0.209$ & 0.9897 & 20） \\
\hline & $\mathrm{Cr}$ & 2699 & 25.2 & $0.056-0.326$ & 0.9908 & \\
\hline & $\mathrm{Mn}$ & 2699.8 & +21.6 & $0.038-0.746$ & 0.9981 & 18) \\
\hline & $\mathrm{Fe}$ & $2700^{\circ}$ & $\begin{array}{l}+51.5_{7} \\
\end{array}$ & $0.005-0.025$ & 0.9535 & 4) \\
\hline & $\mathrm{Mg}_{2} \mathrm{Si}$ & 2704 & $\overline{-11.8_{4}}$ & $0.52-1.44$ & 0.9836 & 22) \\
\hline \multirow{3}{*}{$\mathrm{Mg}$} & $\mathrm{Zn}$ & 1737 & +18.3 & $2.26-10.2$ & 0.998 & 10) \\
\hline & $\mathrm{Al}$ & 1734 & ${\overline{+7.3_{8}}}$ & $1.58-14.2$ & 0.9996 & 14) \\
\hline & $\mathrm{Zr}$ & 1736.5 & $+\longdiv { 1 5 . 3 _ { 4 } }$ & $0.196-0.586$ & 0.9835 & 23) \\
\hline
\end{tabular}
obtained from regression of density measured on various solid solutions of different composition.

Underlined values were mistaken in abstract of 98th annual meeting of Japan Institute of Light Metals (JILM), (2000), p. 245-246.

で， $\mathrm{Al}-\mathrm{Cr}$ 合金は $0.056 \sim 0.326 \%$ とその間の 0.123， 0.211， $0.271 \%$ の計 5 組成を溶体化処理状態で測定した。

Table 1 および Table 2 で計算した $\Delta D$ と Table 3 の実測值 を，両者に共通する合金系で比較すると，両者はかなりよく 一致している。Fig. 1 の $\mathrm{Mg}-\mathrm{Al}$ 合金の密度は鋳造材で測定さ れており，微細な気孔などの鋳造欠陥のために，実測密度は 計算值より低くなった。 $\Delta D$ は Table 2 の計算值とほぼ一致 し, 気孔体積率が $\mathrm{Al}$ 含有量に無関係であることを示唆して いる。

アルミニウム合金の密度は，大部分圧延材で測定したので 鋳造材よりは高くなっているであろうが，冷間圧延で導入さ れた高密度の転位線が, 密度を低下させる可能性がある。こ の点については, 後に 4.3 節で検討する。

\section{2 多元系への拡張}

(6) 式が

$$
D / \mathrm{kg} \mathrm{m}^{-3}=D_{0}+\sum \Delta D^{i}\left(C^{i} / \mathrm{mass}^{\%} \%\right)
$$

のように多元系まで拡張できれば，複雑な多元実用合金の密 度も簡単に推定できる。Fig. 2 は, Table 4 に組成を示した 高純 $\mathrm{Al}-\mathrm{Zn}-\mathrm{Mg}$ 三元系合金での実測密度と（7）式による計 算值を比較している。図中に記入した数字は Table 4 の試料 番号である。

分析值からの計算結果と, 実測值はかなりよく一致してい る。この場合には，(9）式による多元系への拡張が可能で, Table 3 の $\Delta D$ が有効であることが明らかになった。

Fig. 3 では，鉄を含んだ 6063 相当の $\mathrm{Al}-\mathrm{Mg}-\mathrm{Si}$ 合金に銅を 添加 ${ }^{24)}$ した試料の $83 \%$ 冷間圧延状態の実測值と銅添加量と の関係を示す。添加量とともに密度は増加し，その勾配は $\mathrm{Al}-\mathrm{Cu}$ 二元系で得たものよよく一致している。右図には板幅 


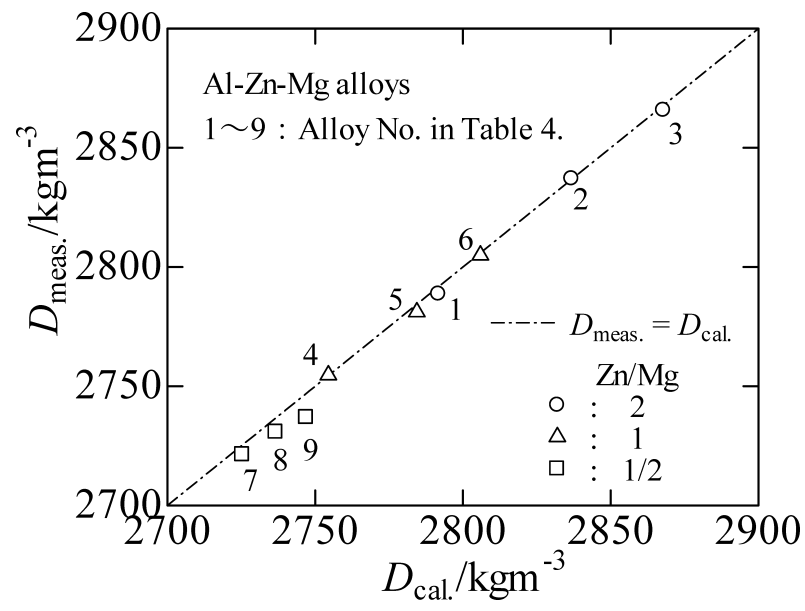

Fig. 2 Comparison of calculated density according to equation (9) and values in Table 3 with measured values of high purity $\mathrm{Al}-\mathrm{Zn}-\mathrm{Mg}$ alloys.

Table 4 Chemical content/mass $\%(a t \%)$ of $\mathrm{Zn}$ and $\mathrm{Mg}$ in high purity $\mathrm{Al}-\mathrm{Zn}-\mathrm{Mg}$ alloys employed for density measurement in Fig. 3. Analysed content of other impurities, $\mathrm{Fe}, \mathrm{Si}, \mathrm{Cu}, \mathrm{Mn}, \mathrm{Cr}$ and $\mathrm{Ti}$ was below $0.01 \mathrm{mass} \%$.

\begin{tabular}{c|c|c}
\hline \hline Alloy No. & Zn & $\mathrm{Mg}$ \\
\hline 1 & $6.17(2.64)$ & $1.22(1.40)$ \\
2 & $9.02(3.92)$ & $1.83(2.14)$ \\
3 & $10.92(4.80)$ & $2.07(2.45)$ \\
4 & $4.34(1.84)$ & $1.71(1.94)$ \\
5 & $6.62(2.85)$ & $2.59(2.99)$ \\
6 & $8.30(3.56)$ & $3.28(3.81)$ \\
7 & $3.17(1.33)$ & $2.37(2.67)$ \\
8 & $4.73(2.00)$ & $3.71(4.22)$ \\
9 & $6.04(2.57)$ & $4.77(5.46)$ \\
\hline
\end{tabular}

$\Delta D^{\mathrm{Si}}$ is calculated from changing lattice constant. $\Delta D^{\mathrm{Mg} 2 \mathrm{Si}}$ is calculated from measured value on $\mathrm{Al}-\mathrm{Mg}_{2} \mathrm{Si}$.

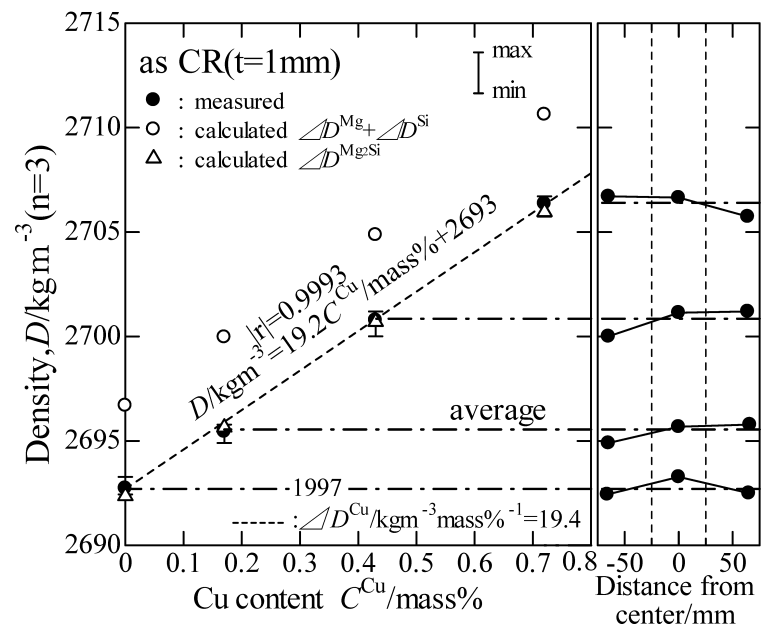

Fig. 3 Effect of $\mathrm{Cu}$ addition on measured density of $\mathrm{Al}-1.0 \% \mathrm{Mg}_{2} \mathrm{Si}$ alloys containing $0.16 \% \mathrm{Fe}^{23)}$, compared with calculated values from the $\Delta D$ in Table 3 and the measured $\Delta D$ for $\mathrm{Al}-\mathrm{Cu}$ binary alloys ${ }^{16)}$.
方向に三分割した同一試料での測定値を示した。試料採取位 置による变動は平均値の $\pm 1 \mathrm{~kg} \mathrm{~m}^{-3}$ 以内に収まっている。回 帰直線の相関係数も充分 1 に近く, 回帰直線之実測密度平均 值との偏差も $0.1 \mathrm{~kg} \mathrm{~m}^{-3}$ の桁なので，これらの定数を使った 密度の計算値は有効数字 4 桁までは充分に信頼できる。

Table 3 の $\mathrm{Mg}_{2} \mathrm{Si}$ の $\Delta D$ を使った計算值は, 実測値とよく 一致したが， $\mathrm{Al}-\mathrm{Mg}, \mathrm{Al}-\mathrm{Si}$ 二元系の $\Delta D$ を使った計算値は, 密度にして $5.4 \mathrm{~kg} \mathrm{~m}^{-3}$, 約 $0.2 \%$ 実測值より大きくなった。冷 間圧延で導入された高密度の転位線が, 実測密度を低下させ ている可能性がある。

Table 1 の固溶状態の格子定数から算出した $\mathrm{Si}$ と $\mathrm{Mg}$ の $\Delta D$

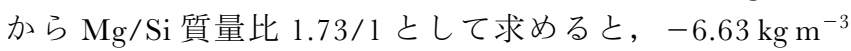
mass $\% \mathrm{Mg}_{2} \mathrm{Si}^{-1}$ となり, Table 3 の $\mathrm{Mg}_{2} \mathrm{Si}$ の值からのものより 高い密度計算值を与えることになる。これらの不一致の原因 としては, 通常 $X \leqq 0.01$ とされる希薄固溶体の溶質分率の上 限を越えた組成の二元系で決定された $\Delta D$ が，第一に上げら れよう。ある格子点が溶質原子で占められる確率は $X$ であ り, FCC では $12 X^{2}$ が統計的二原子クラス夕の存在確率にな る。同種または異種溶質原子間の吸引や反発相互作用を考慮 した検討が，今後の課題である。

\section{3 固溶・析出処理と冷間加工の影響}

$\mathrm{Al}-\mathrm{Mg}$ 二元合金での経験 ${ }^{16)}$ から，溶質濃度が高いほど，圧

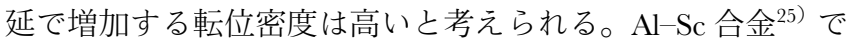
同一圧延率での転位密度増加は, 析出させた状態の方が大き いことを観察している。ただし， $\mathrm{Al}-5 \sim 8 \mathrm{mass} \% \mathrm{Mg}$ 合金でも $92 \%$ 冷間圧延状態の密度は焼なまし状態のものより $1.5 \sim 2.3 \mathrm{~kg} \mathrm{~m}^{-3}$ 小さいだけであった16)。

Table 3 に示した $\mathrm{Mg}_{2} \mathrm{Si} の \Delta D$ は，析出物量が多いほよ゙大 きく増大する転位密度の影響で, 焼なまし状態の数值よりや や低くなっていた可能性はあるが，それほど大きな低下では ないだろう。

焼なまし時に表面に生じる酸化被膜は, コランダムで $3.98 \sim 4.02 \times 10^{3} \mathrm{~kg} \mathrm{~m}^{-3}, \mathrm{MgO}$ で $3.58 \times 10^{3} \mathrm{~kg} \mathrm{~m}^{-3}$ といずれあア ルミニウム合金より密度が大きい。このため焼なましによる 密度増加の定量には酸化被膜の除去が必要であるが，燒なま した $\mathrm{Al}-3.8 \% \mathrm{Mg}$ 合金でも高濃度合金と同程度（約 $0.2 \% ） の$ 密度増加が観察された5)。

Fig. 4 は図中に示した組成の 6N01合金 $\mathrm{T} 5$ 材に, $623 \mathrm{~K}-3.6 \mathrm{ks}$ 保持後炉冷の焼なましを施し, 厚さ $4 \mathrm{~mm}$ から $0.54 \mathrm{~mm}$ まで $87 \%$ 冷間圧延した状態 (CR), 溶体化処理水焼 入れ状態 (STQ), 表面酸化被膜除去後 (polish), および最 後にもう一度, $623 \mathrm{~K}-3.6 \mathrm{ks}$ 保持後炉冷の焼なましをしたと き（F.C.）の密度変化を示す。わずかに幅が異なる試料寸法 と, 研磨による減量む図中に示した。

CR 状態から STQすると, 約 $6 \mathrm{~kg} \mathrm{~m}^{-3}$ の増加が認められ る。転位密度減少と溶質濃度増加が原因と考元られるが, 研 磨による密度減少は $0.5 \mathrm{~kg} \mathrm{~m}^{-3}$ 程度で, 酸化被膜の影響は大 きくない。この試料をもう一度焼なますと, 最初の状態と同 程度にまで析出が進むが, 密度の低下は $1 \sim 2 \mathrm{~kg} \mathrm{~m}^{-3}$ 程度で あった。

最終焼なまし状態と最初の CR 状態の数值とを比較すると, $87 \% \mathrm{CR}$ による密度低下は約 $5 \mathrm{~kg} \mathrm{~m}^{-3}$ で, 測定值の $0.2 \%$ 程 度である。

$\alpha$ 鉄から $\gamma$ 鉄への相変態で, $\mathrm{BCC}$ から FCC の結晶構造変 


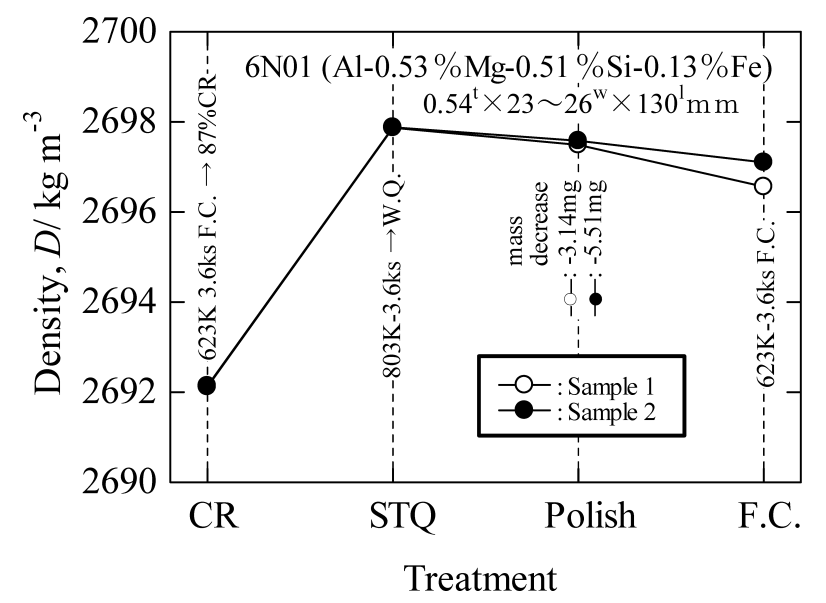

Fig. 4 Change in density of a cold rolled 6N01 alloy by heat treatments.

化だけから予測される体積減少より小さな数值が観測される。 高温 X 線回折で求めた格子定数からも, BCG 状態でのもの より FCG 状態での鉄の原子半径が大きくなっていることが 知られている ${ }^{26)}$ 。化学平衡と同様に, この場合も状態変化を 小さくする方向に変化が起こっている。

析出によって溶質濃度が減っても, 合金元素の原子が消滅 したわけではなく, 析出物として系内に残っている。固溶状 態か析出状態かによる密度变化は，合金組成を変えたり，転 位密度を増加させた場合のものより小さくなるのが当然であ ろう。

\section{5. 結言}

原子分率を使った二元系希薄固溶体の密度の組成依存性を 表す式を誘導し，これまでの測定值を現場で便利な質量 \% か らの計算に使用できる数值で整理した。多元系への拡張を試 み, $\mathrm{Al}-\mathrm{Zn}-\mathrm{Mg}, \mathrm{Al}-\mathrm{Mg}-\mathrm{Si}-\mathrm{Cu}$ 系にはかなりの高精度で使用 できることが明らかになった。

析出状態で密度が大きく变化することが予想される $\mathrm{Al}-\mathrm{Si}$ 二元系を除いて，広範囲の合金で密度を推定できる。6N01 合金の固溶状態での密度は析出状態より $0.5 \sim 1 \mathrm{~kg} \mathrm{~m}^{-3}$ 高い が，変化率は $0.02 \%$ しかない。 $90 \%$ 程度の冷間圧延で増加し た転位による密度の減少は, 測定值の約 $0.2 \%, 5 \mathrm{~kg} \mathrm{~m}^{-3}$ 程度 であった。

本研究では 10 年以上にわたる密度の測定值を集め, 一般 の使用に便利なように整理した。試料の作成や分析を快く引 き受けて下さった各社と，この間教育研究資金を提供し続け て下さった軽金属奨学会に感謝する。本研究をまとめるため
の費用の一部は, 関西大学工学部共同研究, 平成 13 年度研 究費によった。多数の学生諸君の長期にわたる実験への協力 とあわせて感謝する。

\section{参 考 文 献}

1）長倉三郎ほか編集：岩波理化学辞典，第五版，（1998）， 399.

2） E. J. Hatch : 藤川辰一郎引用『新版アルミニウム技術便覧』, 軽金属協会編，力ロス出版，（1996），p. 22.

3）小松伸也，立松一穂，村上陽太郎，梶山 毅，松尾 守，村松 俊樹：軽金属，35（1985），526。

4）小松伸也, 池田勝彦, 松尾 守, 村松俊樹：軽金属, 41（1991）, 465.

5）小松伸也, 池田勝彦, 田畑義昭, (故) 合田剛久：軽金属, 44 (1994)，439.

6）小松伸也, 池田勝彦, 生駒俊彦, 河野洋一：軽金属, 43 (1993), 421.

7）小松伸也，藤川辰一郎：軽金属，47（1997），170，396.

8）長崎誠三編：改訂増補版金属用語集, 日本金属学会, (1995), p. 127.

9) W. B. Pearson: A Handbook of Lattice Spacings and Structures of Metals and Alloys, Pergamon Press, London, (1958), p. 261.

10）小松伸也, 池田勝彦, 小川兼明：軽金属, 48 (1998), 484.

11) G. Siebel und H. Vosskuehler: Z. Metallkd., 31 (1939), 359.

12) V. G. Kuznetzof and L. N. Guseva: Izv. Akad. Nauk., SSSR. (Khim.) (1940), 905. refered by 9) p. 335, 356.

13） G. Barrow, 藤代亮一訳 : 物理化学, 第 5 版, 東京化学同人, (1990), 415

14）小松伸也, 池田勝彦, 生駒俊彦, 薄永 健, 新谷智彦, 内田博 幸：軽金属, 45 (1995)， 27.

15）小松伸也, 池田勝彦：軽金属学会第 98 回大会講演概要, (2000), 245.

16）小松伸也, 池田勝彦, 河本知広, 田畑義昭, 谷本孝弘：軽金属, 48 (1998), 294.

17）小松伸也，池田勝彦，行待秀晃，柳井雅也：軽金属学会第 93 回大会講演概要, (1997), 43.

18) S. Komatsu, M. Ikeda, K. Komoda, M. Nakaji and M. Matsuo: eds. K. Hirano, H. Oikawa and K. Ikeda, Science and Engineering of Light Metals, Proc. RASELM '91, JILM, Tokyo, (1991), p. 875.

19）池田 毅, 宮下龍成, 丹羽正博, 池田勝彦, 小松伸也：軽金属, 48 (1998), 132.

20) T. Ikeda, T. Miyashita, T. Hirai, M. Ikeda and S. Komatsu: J. JILM, 49 (1999), 476.

21）小松伸也, 池田勝彦, 村上 篤：軽金属学会第 97 回大会講演 概要, (1999), 241.

22）小松伸也, 池田勝彦, 太田敬丈，村上 篤：軽金属学会第 96 回大会講演概要, (1999), 145.

23）小松伸也，池田勝彦，森 海彦，小林道弘：軽金属学会第 90 回大会講演概要，(1996)，279.

24）阿部晴彦，小松伸也，桜井健夫，池田勝彦：軽金属，52 (2002), 179.

25）小松伸也，池田勝彦，村上 篤，荻原寛之：軽金属学会第 100 回大会講演概要，(2001)，159.

26）石田清仁，大沼郁雄，早稲田嘉夫ほか編集：改訂 6 版金属便 覧，丸善，（2000）, p. 473. 